\title{
Dalangtan Saline Playa in a Hyperarid Region on Tibet Plateau: I. Evolution and Environments
}

\author{
Fanjing Kong, Mianping Zheng, ${ }_{1}^{1}$ Bin $\mathrm{Hu}^{1,2}$ Alian Wang, Nina Ma, and Pablo Sobron ${ }^{4,5}$
}

\begin{abstract}
Since 2008, we have been studying a saline lake, Dalangtan (DLT) Playa, and its surroundings in a hyperarid region of the Qaidam Basin on the Tibetan Plateau as a potential Mars analog site. We describe the evolution of saline deposits in the Qaidam Basin (including DLT), based on investigative findings accumulated over the course of 60 years of geological surveys. In addition, we report regional meteorological patterns recorded for the past 32 years along with meteorological station recorded data at DLT since 2012. Overall, the DLT area on the Tibetan Plateau has low atmospheric pressure, high ultraviolet radiation, low annual mean temperatures (T) but large seasonal and diurnal T cycles, and extremely low relative humidity, all of which bear some similarities with the equatorial region on Mars. In addition, salt types similar to those found on Mars, such as magnesiumsulfates, chlorides, and perchlorates, are found at the surface and subsurface in the DLT area (and the other two playas in the Qaidam Basin), thus supporting DLT as a Mars analog in terms of mineralogy and geochemistry. Key Words: Mars analog—Tibet Plateau—Saline playa_Evolution—Climatology. Astrobiology 18, 1243-1253.
\end{abstract}

\section{Introduction}

Q TUdies of terRestrial analog sites have played an essential role in understanding observations from past missions. Although no site on Earth is a perfect analog to specific regions on Mars, individual analog sites on Earth do provide important scientific results that support fundamental science as applied to Mars and Mars missions.

Since 2008, our team has been studying the saline lake, Dalangtan (DLT) Playa, and its surroundings in the hyperarid region (Qaidam Basin) on the Tibetan Plateau in China as a potential Mars analog site (Kong et al., 2009, 2010; Mayer et al., 2009; Sobron et al., 2009; Wang and Zheng, 2009, 2011; Zheng et al., 2009; Wang et al., 2010, 2013; Anglés and Li, 2017a, 2017b; Cheng et al. 2017; Xiao et al., 2017). This article describes the evolution of saline deposits in the Qaidam Basin, based on the knowledge accumulated through
60 years of geological survey and detailed ground investigations (e.g., Zhang, 1987; Zhu et al., 1994; Zheng, 1997; Kong et al., 2014a, 2014b). In addition, we report on regional meteorological patterns averaged for the past 32 years. This is one of three articles based on our investigations of the DLT saline playa. In the second article, we report the analysis of the collected subsurface samples from two vertical stratigraphic cross sections at the DLT Playa, with an emphasis on mineralogy and geochemistry (Wang et al., 2018). In the third article of this series (Sobron et al., 2018), we report a multiscale mineralogy and geochemistry study of surface salts in an anticline in DLT (site 02).

This article discusses the salt precipitation history (through the Paleocene and to Pleistocene period) and distribution at different playas in Qaidam Basin along with the regional climate pattern. We note observed climatic, mineralogical,

\footnotetext{
${ }^{1}$ MLR Key Laboratory of Saline Lake Resources and Environments, Institute of Mineral Resources, Chinese Academy of Geological Sciences, Beijing, China.

${ }^{2}$ Institute of Geology and Geophysics, Chinese Academy of Sciences, Beijing, China.

${ }^{3}$ Department of Earth and Planetary Sciences, McDonnell Center for Space Sciences, Washington University in St. Louis, St. Louis, Missouri.

${ }_{5}^{4}$ SETI Institute, Mountain View, California.

${ }^{5}$ Impossible Sensing, St. Louis, Missouri.

(c) Fanjing Kong et al., 2018; Published by Mary Ann Liebert, Inc. This Open Access article is distributed under the terms of the Creative Commons Attribution Noncommercial License (http://creativecommons.org/licenses/by-nc/4.0/) which permits any noncommercial use, distribution, and reproduction in any medium, provided the original author(s) and the source are credited.
} 
and geochemical similarities between the basin and some salt-rich areas on Mars.

\section{Evolution of Saline Playas in Qaidam Basin}

The Qaidam Basin is located in the northeast region of the Qinghai-Tibet (QT) Plateau. The QT Plateau has an average elevation of $4500 \mathrm{~m}$ and comprises five massive mountain chains that are east-west oriented and includes the Himalaya mountain chain (the highest among the five, average elevation of $\sim 6100 \mathrm{~m}$ ) to the south. This setting blocks the humid Indian monsoon to Qaidam Basin, which has the lowest average elevation ( $2676 \mathrm{~m}$, the Senie Lake) on the QT Plateau. The Qaidam Basin is thus one of the driest places in nonpolar regions on Earth, with an aridity index (AI) of 0.008-0.04 recorded at specific locations (Zhu et al., 1994).

The Qaidam Basin is surrounded by the Qilian Mountains in the northeast, the Aljin Mountains in the northwest, and the Kunlun Mountains in the south (Fig. 1). This basin terrain began to subside, due to the opposite strike-slip of three deep faults that extend along each of the three mountain ranges, and then form the primary phase of the Qaidam sedimentary basin during the Mesozoic. The high elevation of the Qaidam Basin (2700-3300 m) results in low mean annual temperatures $(\mathrm{T})$, large diurnal and seasonal $\mathrm{T}$ variations, and high ultraviolet radiation. These environmental conditions, in addition to hyperaridity, cause the evaporation of water bodies in the Qaidam Basin and the precipitation of various salts. The Qaidam Basin features four major saline playas that formed from brine evaporation in its internal depressions.

The landforms of the Qaidam Basin have evolved since its formation. Since the Paleocene, starting with the collision between the Eurasia and India plates, the Qaidam Basin has experienced periods of subsidence, and a thick layer of sediments (up to $2600 \mathrm{~m}$ ) has formed in the basin.
In addition, regional tectonic activity, especially the uplift of the Tibetan Plateau, together with the deposition process itself, has altered the location of the depositional center several times within the basin.

The bases of the Qaidam Basin are thrust faults and strike slip faults, with main continental deposits in Mesozoic and Cenozoic. Triassic strata are absent over the basin, and deposits in Mesozoic, Jurassic, and Cretaceous are distributed in the northern margin of the basin. Jurassic strata is a set of river and lake facies, and coal-bearing swamp facies sediments with a thickness of $500 \mathrm{~m}$, which indicates that the northern part of the Qaidam Basin was a freshwater lake in that time, with $\mathrm{T}$ consistent with a humid, subtropical climate. In the Cretaceous, a set of continental red clastic rock series developed that are mainly distributed in the northern margin of the basin. The sedimentary range was much more extensive than before. With the climate beginning to dry and water bodies changing from deep to shallow, the Qaidam Basin was essentially a collection of alluvial plains and shallow lakes.

The Cenozoic sedimentary strata developed most extensively in the Qaidam Basin and covered the whole basin. In addition, the main sedimentary formation from the Paleogene to the Neogene has been found in the western depression with a thickness of 1252-10,546 m. Sedimentary processes occurred from the upper Paleocene to the Pliocene, but the Quaternary sedimentary materials are located primarily in the eastern part of the basin. From the beginning of the early Pleistocene, a large number of salt deposits formed, most of them of 2000-3400 m thickness. Deposition occurred from the upper Paleocene to Pliocene, and gypsum salt sedimentation started to occur in the Oligocene; salt deposition was most prevalent during the Miocene.

In summary, the climate of the basin since the Cenozoic has become increasingly dry. Owing to the collision of the

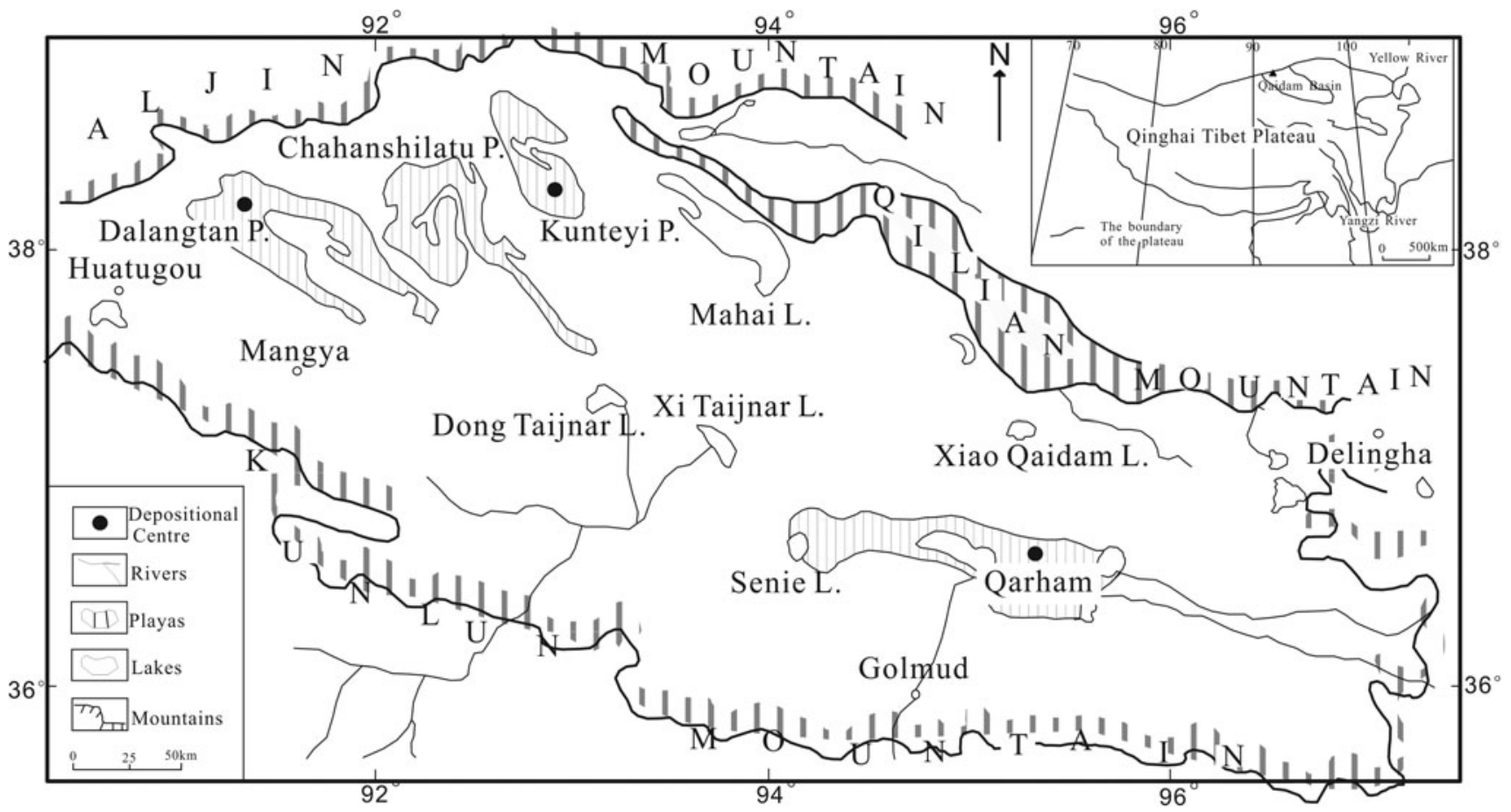

FIG. 1. Schematic map of Qaidam Basin. 
India plate and the Asian plate, the sedimentary center of the lake in the Qaidam Basin has migrated from the northwest to the east. By the late Pliocene, the center shifted from the northwest to the east of the basin, where the DLT Playa formed.

The Qaidam Basin is a closed drainage basin. River systems are mainly recharged by snowmelt from the surrounding mountains, whereas spring waters from deep faults and meteoritic water supply the modern lakes in the interior. Surface water bodies react with atmospheric water and with previously deposited salt-rich sediments, becoming salt ion rich. Therefore, the water chemistry of modern salt lakes in the Qaidam Basin is greatly controlled by the nature of local salt sediments. The long and complex history of salt deposits in the Qaidam Basin, especially the migration of the salt depositional center with time, has generated three major playas with different salt types: Mg-sulfate-rich DLT, chloride-rich Qarhan, and sulfate-chloride-rich Kunteyi.

\subsection{Sulfate-rich sediments at the DLT Playa}

As discussed previously, sulfate-rich sediments dominated during the first major salt forming period in the Pliocene and are distributed widely in the west and northwest parts of the Qaidam Basin. During this period, the sulfaterich sediments first deposited at areas centered at the DLT secondary basin (aka DLT area, 38 $0^{\circ}-38^{\circ} 40^{\prime} \mathrm{N}, 91^{\circ} 10^{\prime}-$ $\left.92^{\circ} 10^{\prime} \mathrm{E}\right)$, then extended to the northwest Qaidam Basin. In the late Pliocene, only a small amount of high-salinity sulfate brine was left in local depressions including the DLT depression, which eventually dried up during the Holocene to form the DLT Playa.
The DLT Playa is located in the center depression of the DLT area on the west margin of Qaidam Basin. The mineralogy of surface and shallow subsurface strata has been described in several studies (Zheng, 1997, 2009; Wang et al., 2018). The predominant sulfate phase in the strata at the edge of the DLT area is mirabilite, a hydrated sodium sulfate, $\mathrm{Na}_{2} \mathrm{SO}_{4} \cdot 10 \mathrm{H}_{2} \mathrm{O}$. The strata at the center of the DLT Playa are composed mostly of hexahydrite, a hydrated magnesium sulfate, $\mathrm{MgSO}_{4} \cdot 6 \mathrm{H}_{2} \mathrm{O}$. Bloedite, $\mathrm{Na}_{2} \mathrm{Mg}\left(\mathrm{SO}_{4}\right)_{2} \cdot 4 \mathrm{H}_{2} \mathrm{O}$, was also identified in the DLT area (Table 1). This deposition trend from $\mathrm{Na}$ sulfate to $\mathrm{Mg}$ sulfate follows the normal geochemical evolution trend and the precipitation sequence of sulfate brines. The common occurrence of halite at the surface of the DLT and in samples collected from shallow subsurface strata at various locations of the playa supports the notion that the residual sulfate-rich brine from the first major salt forming period in the Pliocene reached the stage of halite saturation. In addition, $\mathrm{ClO}_{4}{ }^{-}$and $\mathrm{ClO}_{3}{ }^{-}$were detected in shallow subsurface regolith of the DLT Playa (Wang et al., 2018, this volume).

\subsection{Chloride-rich sediments at Qarhan Playa}

In the second major salt forming period of Qaidam Basin during the Pleistocene, chloride-rich sediments deposited at regions centered at the Qarhan lake area (Fig. 1). The chlorine-rich brine originated by way of migration from the west Qaidam Basin into the Qarhan depression, which eventually evaporated and formed the Qarhan Playa. Qarhan Playa is a large dry area in the Qarhan lake region $\left(36^{\circ} 37^{\prime}-37^{\circ} 12^{\prime} \mathrm{N}\right.$, $\left.93^{\circ} 42^{\prime}-96^{\circ} 14^{\prime} \mathrm{E}\right)$ at the center of the Qaidam Basin. Chloriderich minerals, mainly halite $\mathrm{NaCl}$, have been observed in the

Table 1. Salt Minerals Found in Three Saline Playas in Qaidam Basin and in Mars

\begin{tabular}{|c|c|c|c|c|c|}
\hline Minerals & Chemistry & DLT Playa & Kunteyi Playa & Qarhan Playa & Mars \\
\hline Gypsum & $\mathrm{CaSO}_{4} \cdot 2 \mathrm{H}_{2} \mathrm{O}$ & Yes & Yes & Yes & Yes \\
\hline Bassanite & $\mathrm{CaSO}_{4} \cdot 1 / 2 \mathrm{H}_{2} \mathrm{O}$ & Yes & Yes & & \\
\hline Anhydrite & $\mathrm{CaSO}_{4}$ & Yes & & Yes & \\
\hline Mirabilite & $\mathrm{Na}_{2} \mathrm{SO}_{4} \cdot 10 \mathrm{H}_{2} \mathrm{O}$ & Yes & Yes & & \\
\hline Thenardite & $\mathrm{Na}_{2} \mathrm{SO}_{4}$ & Yes & Yes & & \\
\hline Epsomite & $\mathrm{MgSO}_{4} \cdot 7 \mathrm{H}_{2} \mathrm{O}$ & Yes & & & \\
\hline Hexahydrite & $\mathrm{MgSO}_{4} \cdot 6 \mathrm{H}_{2} \mathrm{O}$ & Yes & Yes & & \\
\hline Pentahydrite & $\mathrm{MgSO}_{4} \cdot 5 \mathrm{H}_{2} \mathrm{O}$ & Yes & & & \\
\hline Starkeyite & $\mathrm{MgSO}_{4} \cdot 4 \mathrm{H}_{2} \mathrm{O}$ & Yes & Yes & & Yes \\
\hline Kieserite & $\mathrm{MgSO}_{4} \cdot \mathrm{H}_{2} \mathrm{O}$ & Yes & & & Yes \\
\hline Bloedite & $\mathrm{Na}_{2} \mathrm{Mg}\left(\mathrm{SO}_{4}\right)_{2} \cdot 4 \mathrm{H}_{2} \mathrm{O}$ & Yes & Yes & & \\
\hline Glauberite & $\mathrm{Na}_{2} \mathrm{Ca}\left(\mathrm{SO}_{4}\right)_{2}$ & Yes & Yes & & \\
\hline Glaserite & $\mathrm{K}_{3} \mathrm{Na}\left(\mathrm{SO}_{4}\right)_{2}$ & Yes & & & \\
\hline Leonite & $\mathrm{K}_{2} \mathrm{Mg}\left(\mathrm{SO}_{4}\right)_{2} \cdot 4 \mathrm{H}_{2} \mathrm{O}$ & Yes & & & \\
\hline Langbeinite & $\mathrm{K}_{2} \mathrm{Mg}_{2}\left(\mathrm{SO}_{4}\right)_{3}$ & Yes & & & \\
\hline Loeweite & $\mathrm{Na}_{12} \mathrm{Mg}_{7}\left(\mathrm{SO}_{4}\right)_{13} \cdot 15 \mathrm{H}_{2} \mathrm{O}$ & Yes & Yes & & \\
\hline Polyhalite & $\mathrm{K}_{2} \mathrm{MgCa}\left(\mathrm{SO}_{4}\right)_{3} \cdot 2 \mathrm{H}_{2} \mathrm{O}$ & Yes & Yes & & \\
\hline Picromerite & $\mathrm{K}_{2} \mathrm{Mg}\left(\mathrm{SO}_{4}\right)_{2} \cdot 6 \mathrm{H}_{2} \mathrm{O}$ & Yes & & & \\
\hline Halite & $\mathrm{NaCl}$ & Yes & Yes & Yes & Yes \\
\hline Sylvite & $\mathrm{KCl}$ & Yes & Yes & Yes & Yes \\
\hline Carnallite & $\mathrm{KMgCl}_{3} \cdot 6 \mathrm{H}_{2} \mathrm{O}$ & Yes & & Yes & \\
\hline Bischofite & $\mathrm{MgCl}_{2} \cdot 6 \mathrm{H}_{2} \mathrm{O}$ & & Yes & Yes & Yes \\
\hline Antarcticite & $\mathrm{CaCl}_{2} \cdot 6 \mathrm{H}_{2} \mathrm{O}$ & & Yes & & \\
\hline Dansite & $\mathrm{Na}_{21} \mathrm{Mg}\left(\mathrm{SO}_{4}\right)_{10} \mathrm{Cl}_{3}$ & Yes & & & \\
\hline
\end{tabular}

Adapted from Zhu et al. (1994), Mohlmann et al. (2011), Kong et al. (2014b), and Wang et al. (2018).

DLT, Dalangtan. 
strata formed in the Pleistocene. Carnallite $\mathrm{KMgCl}_{3} \cdot 6 \mathrm{H}_{2} \mathrm{O}$, sylvite $\mathrm{KCl}$, and bischofite $\mathrm{MgCl}_{2} \cdot 6 \mathrm{H}_{2} \mathrm{O}$ started to form in strata from the Holocene (Table 1), representing the very late evaporation stage of chlorine-rich brine.

\subsection{Deposition transition from sulfates to chlorides at Kunteyi Playa}

During the first major salt deposition period in the Pliocene, the deposition center of Qaidam Basin moved to the northwest, and the sulfate-chloride-bearing brine extended to the Kunteyi saline lake area (upper-middle in Fig. 1). As this migration went on, the brine chemistry evolved to an intermediate stage, transitioning from sulfate rich to chloride rich. Subsequently, these brines partially evaporated and formed the Kunteyi Playa and the Kunteyi Salt Lake.

The Kunteyi Playa has salt-bearing strata up to hundreds of meters thick. In this region, sulfates such as gypsum $\mathrm{CaSO}_{4} \cdot 2 \mathrm{H}_{2} \mathrm{O}$, mirabilite, and glauberite $\mathrm{Na}_{2} \mathrm{Ca}\left(\mathrm{SO}_{4}\right)_{2}$ occur in the lower part of the strata, whereas hydrated chlorides, for example, bischofite $\mathrm{MgCl}_{2} \cdot 6 \mathrm{H}_{2} \mathrm{O}$ and antarcticite $\mathrm{CaCl}_{2} \cdot 6 \mathrm{H}_{2} \mathrm{O}$, occur in the upper part of the strata or the surface of outcrops (Table 1).

\section{Regional Meteorological Patterns}

\subsection{Three data sets}

In this work, we use three data sets to describe the meteorological patterns of the DLT area. The first set is a 32-year record (1980-2011) of meteorology data collected at the Mangya meteorological station, located $<50 \mathrm{~km}$ from the DLT Playa (Fig. 1). Meteorological data were provided by the Qinghai Meteorological Administration. This data set includes T, relative humidity ( $\mathrm{RH})$, atmospheric pressure at the surface, precipitation, evaporation, wind speed, and sunlight hours. These data were recorded each hour. The second set is a 2-year $\mathrm{RH}$ and $\mathrm{T}$ record collected by our team with a data logger RHT10 (Extech Co., Nashua, NH) at the surface of the Xiao Liang Shan anticline $(6 \mathrm{~km}$ to the center of the DLT Playa) since 2010. These data were recorded each hour and were downloaded every 3-6 months. The third set is from a new meteorological station set up by us at the center of the DLT Playa in 2012, from which the data have been collected to the present and recorded each hour. All three playas in the Qaidam Basin, as discussed in Section 2, formed at local depressions and have quite similar elevations: $2690 \mathrm{~m}, 2670 \mathrm{~m}$, and $2730 \mathrm{~m}$ for the DLT, Qarhan, and Kunteyi, respectively. Owing to their proximity and similar elevation, the three regions are subject to the same meteorological conditions. Although our data were only collected at, or near, the DLT Playa, the DLT measurements can be extrapolated to the other two playas.

\subsection{Basic environmental characteristics}

Figures 2, 4, 7-11 show the monthly average $\mathrm{T}$ (in ${ }^{\circ} \mathrm{C}$ ), RH (in \%), lighting (in hours), wind speed (in $\mathrm{m} / \mathrm{s}$ ), precipitation (in $\mathrm{mm}$ ), and evaporation (in $\mathrm{mm}$ ) recorded at Mangya meteorological station $(<50 \mathrm{~km}$ to DLT Playa). Figures 3 and 5 show hourly variations of T and RH in two typical summer and winter days at logger RHT10.

Based on those data, we found that the annual average $\mathrm{T}$ in the DLT area is $3.5^{\circ} \mathrm{C}$. The seasonal variation $\Delta \mathrm{T}_{\text {ave }}$ is $>30^{\circ} \mathrm{C}$ (Fig. 2), but seasonal $\Delta \mathrm{T}_{\text {peak }}$ is $>55^{\circ} \mathrm{C}$ (Fig. 3). The maximum monthly average air $\mathrm{T}$ was $16^{\circ} \mathrm{C}$ in July, with $\mathrm{T}_{\max }>30^{\circ} \mathrm{C}$ occurring in the summer afternoon (Fig. 3). The minimum monthly average air $\mathrm{T}$ was $-10.7^{\circ} \mathrm{C}$ in January, with $\mathrm{T}_{\min }<-25^{\circ} \mathrm{C}$ occurring in the winter early morning (Fig. 3). The diurnal $\mathrm{T}$ variation in summer is about $20^{\circ} \mathrm{C}$, and that value decreases in winter to about $15^{\circ} \mathrm{C}$ (Fig. 3). The

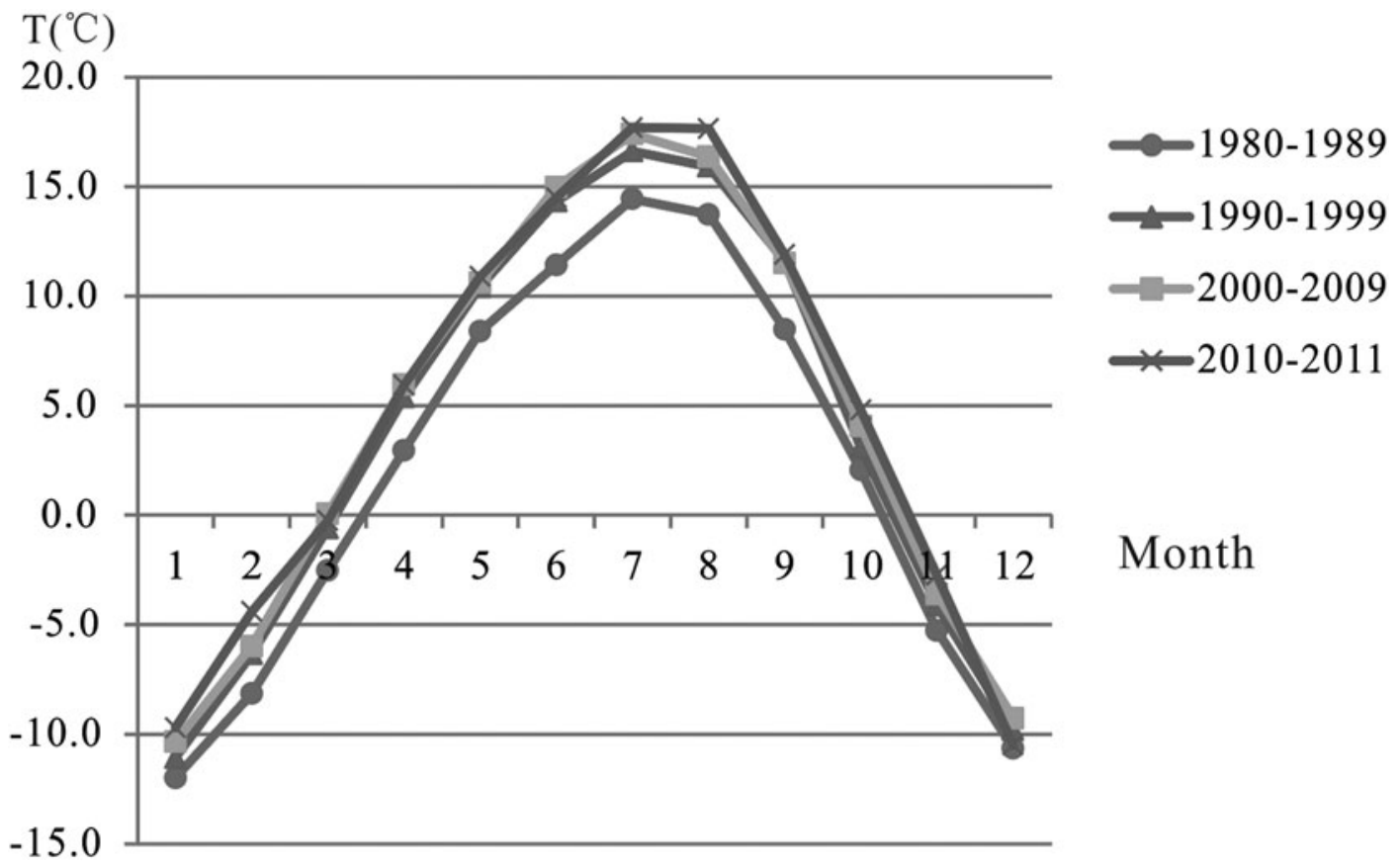

FIG. 2. Patterns of $\mathrm{T}$ (in ${ }^{\circ} \mathrm{C}$, monthly averaged) in 1980-2011, recorded at Mangya Meteorological Station $(<50 \mathrm{~km}$ to DLT Playa). DLT, Dalangtan; T, temperature. 


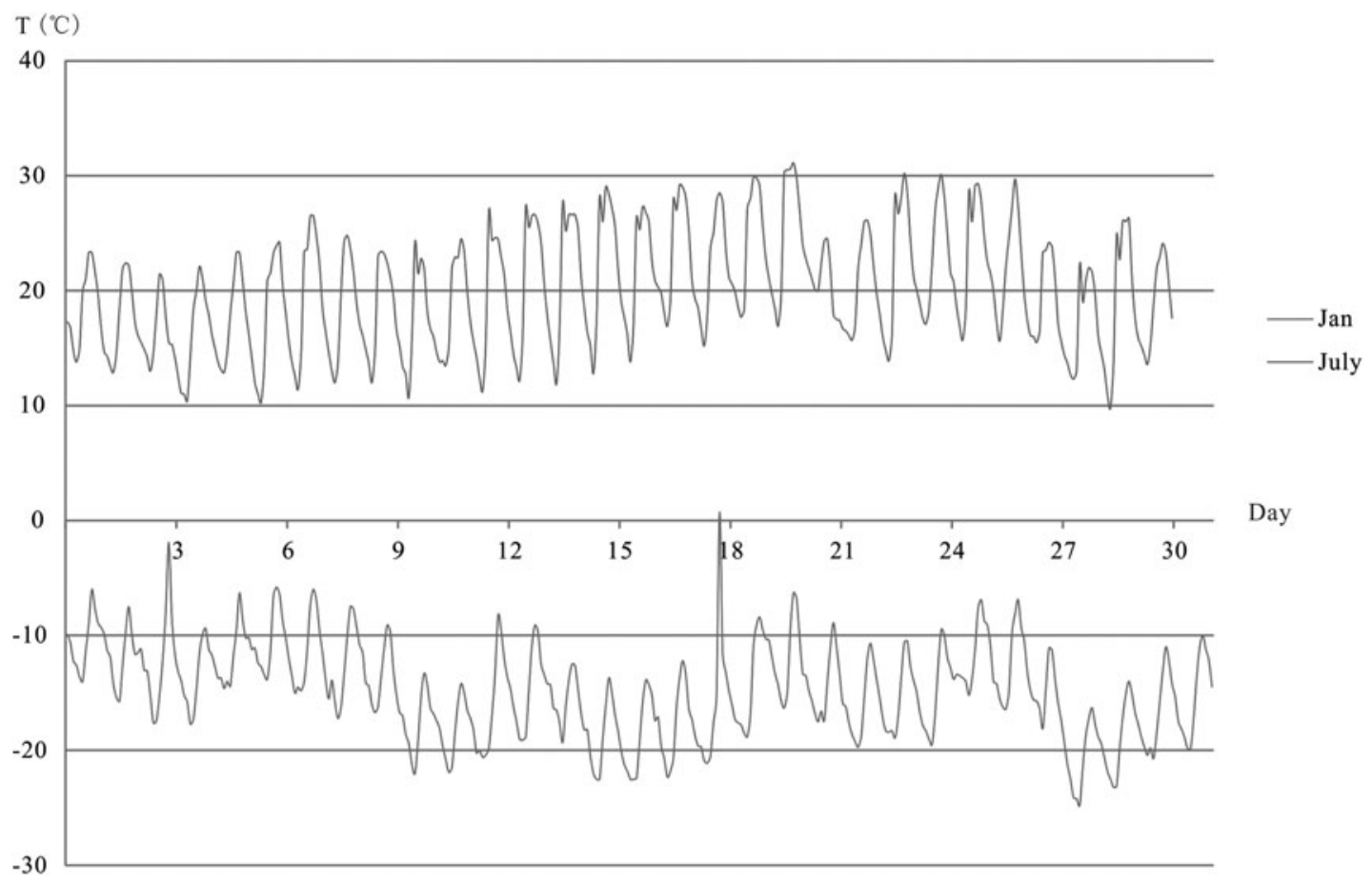

FIG. 3. Diurnal temperature variations during a typical summer month and a winter month recorded at the surface of XLS anticline from $\mathrm{T}$ to $\mathrm{RH} \operatorname{logger}$ data $(<6 \mathrm{~km}$ to the center of DLT Playa). RH, relative humidity; XLS, Xiao Liang Shan.

atmospheric pressure at the surface of the DLT area is about $70 \%$ of atmospheric pressure at sea level. The annual average surface pressure recorded is 709 mbar (Fig. 11). The surface pressure (717 mbar) in autumn is slightly higher than that in spring (706 mbar).
$\mathrm{RH}$ is dependent on $\mathrm{T}$ and the partial pressure of water $\mathrm{P}_{\mathrm{H} 2 \mathrm{O}}$. The DLT area is extremely dry in spring and fall, but less dry in winter and summer when monthly averaged $\mathrm{RH}$ can rise to $>35 \%$, although it never exceeds $40 \%$ (Fig. 4 ). The lowest $\mathrm{RH}$ values $(<10 \%)$ were observed in early afternoon,

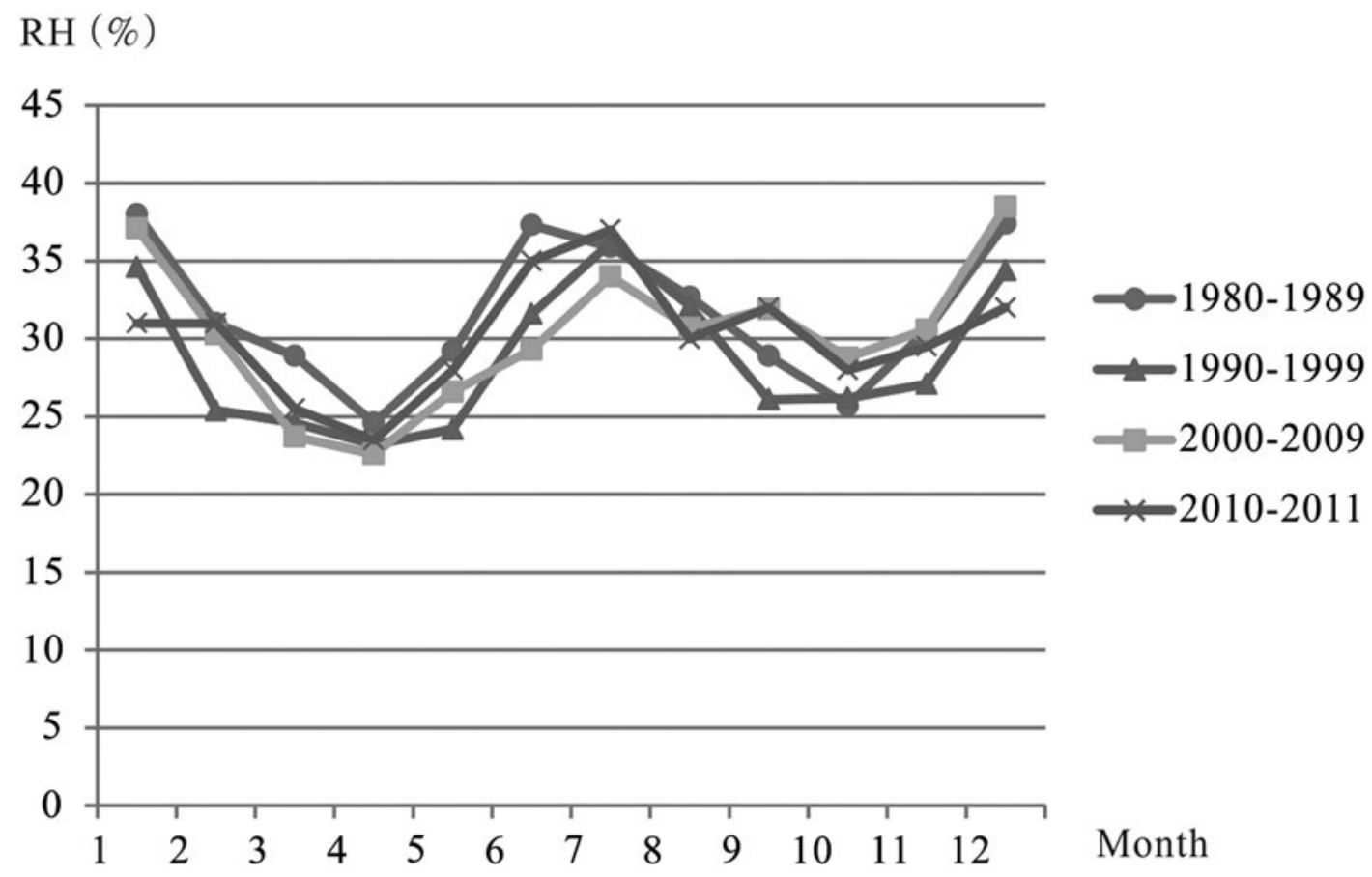

FIG. 4. Patterns of RH (\%, monthly averaged) during 1980-2011, recorded at Mangya Meteorological Station (<50 km to DLT Playa). 


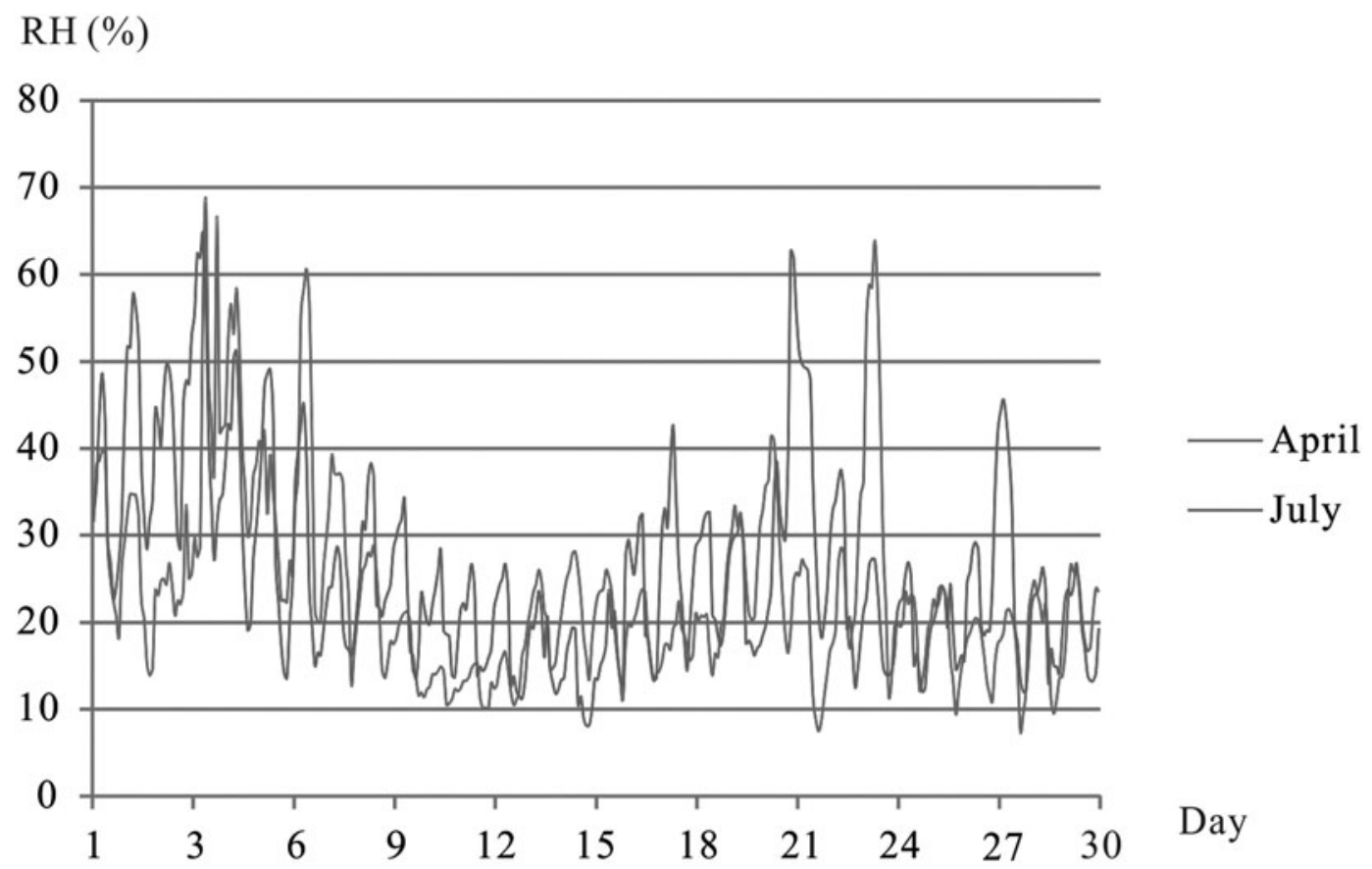

FIG. 5. Diurnal variations in RH during a typical spring month and a winter month recorded at the surface of XLS anticline from $\mathrm{T}$ to $\mathrm{RH} \operatorname{logger}$ data $(<6 \mathrm{~km}$ to the center of DLT Playa).

with a variation of $15 \%$ between months (Fig. 5). The highest RH values $(>60 \%)$ were observed in early morning, with a larger variation $\sim 40 \%$ between months (Fig. 5). No RH value of $100 \%$ was found among our 2 years of recorded data (2010-2011) using an RHT10 logger, which is consistent with the lack of rain in our recording interval.
The changing pattern of water vapor pressures $\left(\mathrm{P}_{\mathrm{H} 2 \mathrm{O}}\right)$ in 2011 is shown in Figure 6. Data were recorded with the logger RHT10, and $\mathrm{P}_{\mathrm{H} 2 \mathrm{O}}$ was calculated based on reference data of saturated water/ice vapor pressures (Haar et al., 1984; Wagner et al., 1994). The results indicate that the water vapor input is stronger from June to August. Water

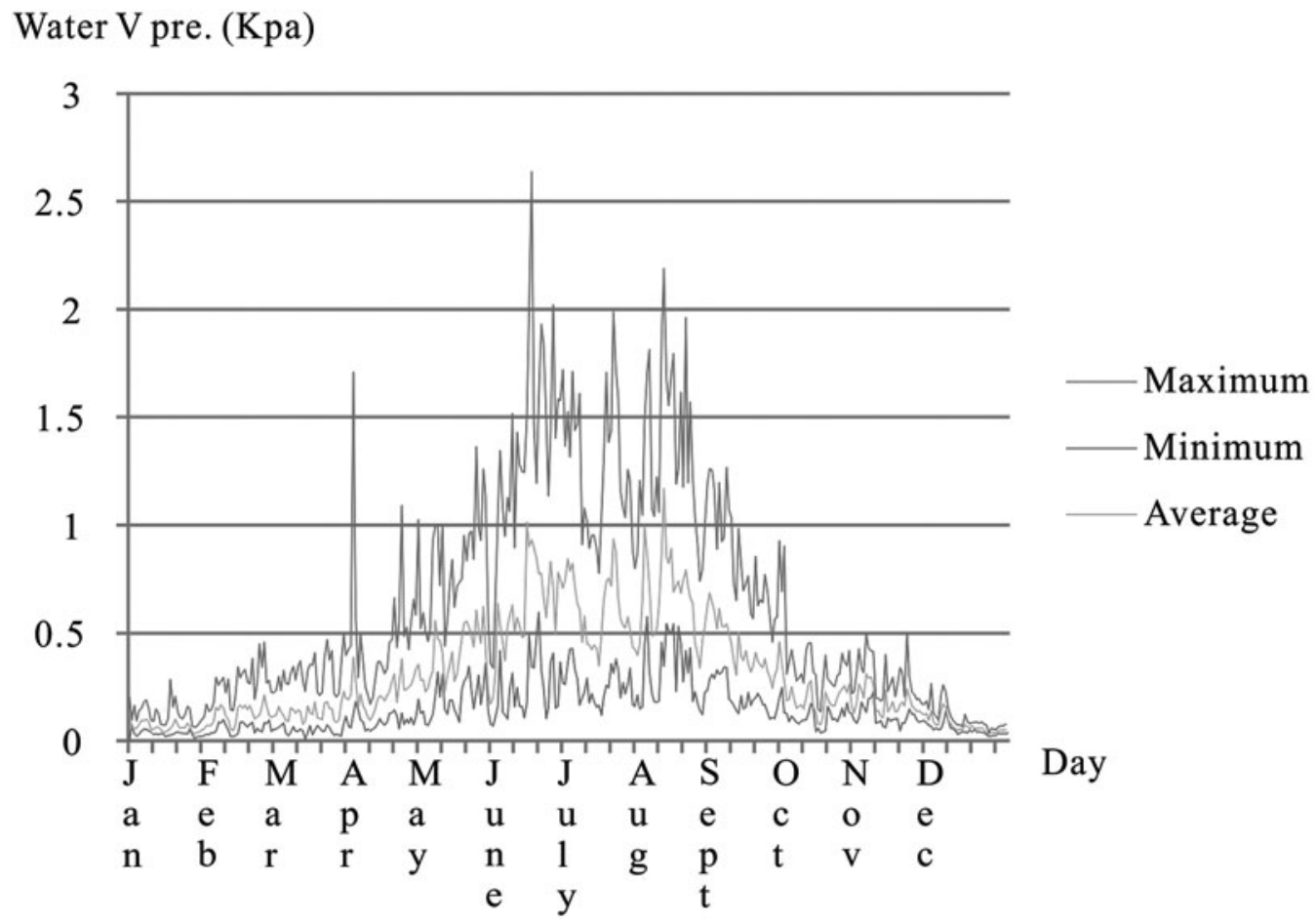

FIG. 6. Water vapor pressures variation at per hour density in 2011 . 
Sunlight (Hrs)

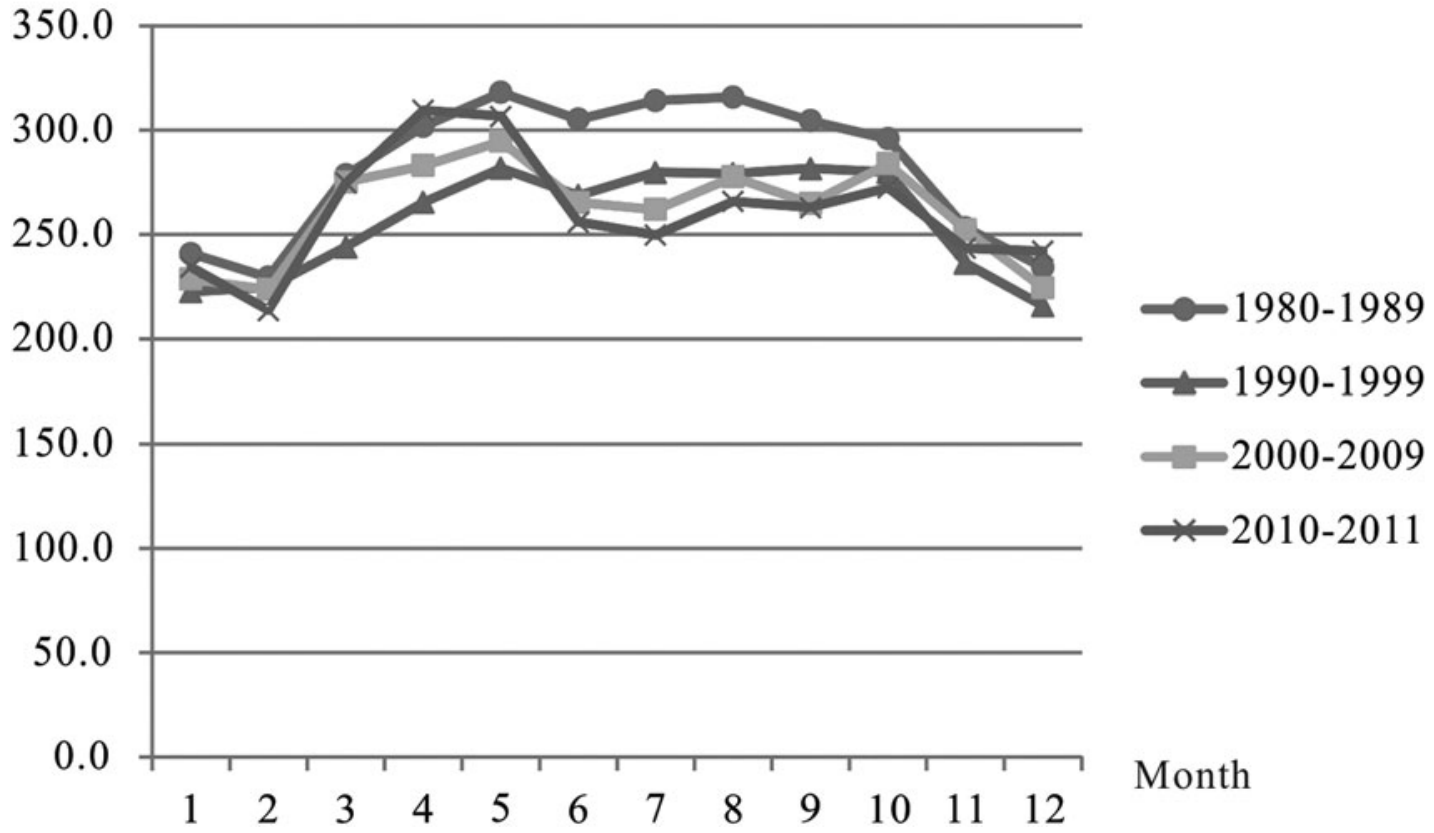

FIG. 7. Lighting hours (monthly average) during 1989-2011 recorded at Mangya Meteorological Station (<50 km to DLT Playa).

vapor transported from the west is the basic water vapor source of the DLT area. West wind fluctuations have a direct effect on the interannual change of the water vapor transport flux divergence over most of Northwest China (Wang et al., 2005). The Indian monsoon affects the southern and eastern parts of Northwest China by the southwest water vapor transport stream (Wang et al., 2005). For the Qaidam Basin, the vapor resources may have the same mechanism according to our observations.

The weather in the DLT Playa is sunny and windy. The monthly average hours of sunlight range from 220 during winter to 320 during summer (Fig. 7). The maximum

Wind speed $(\mathrm{m} / \mathrm{s})$

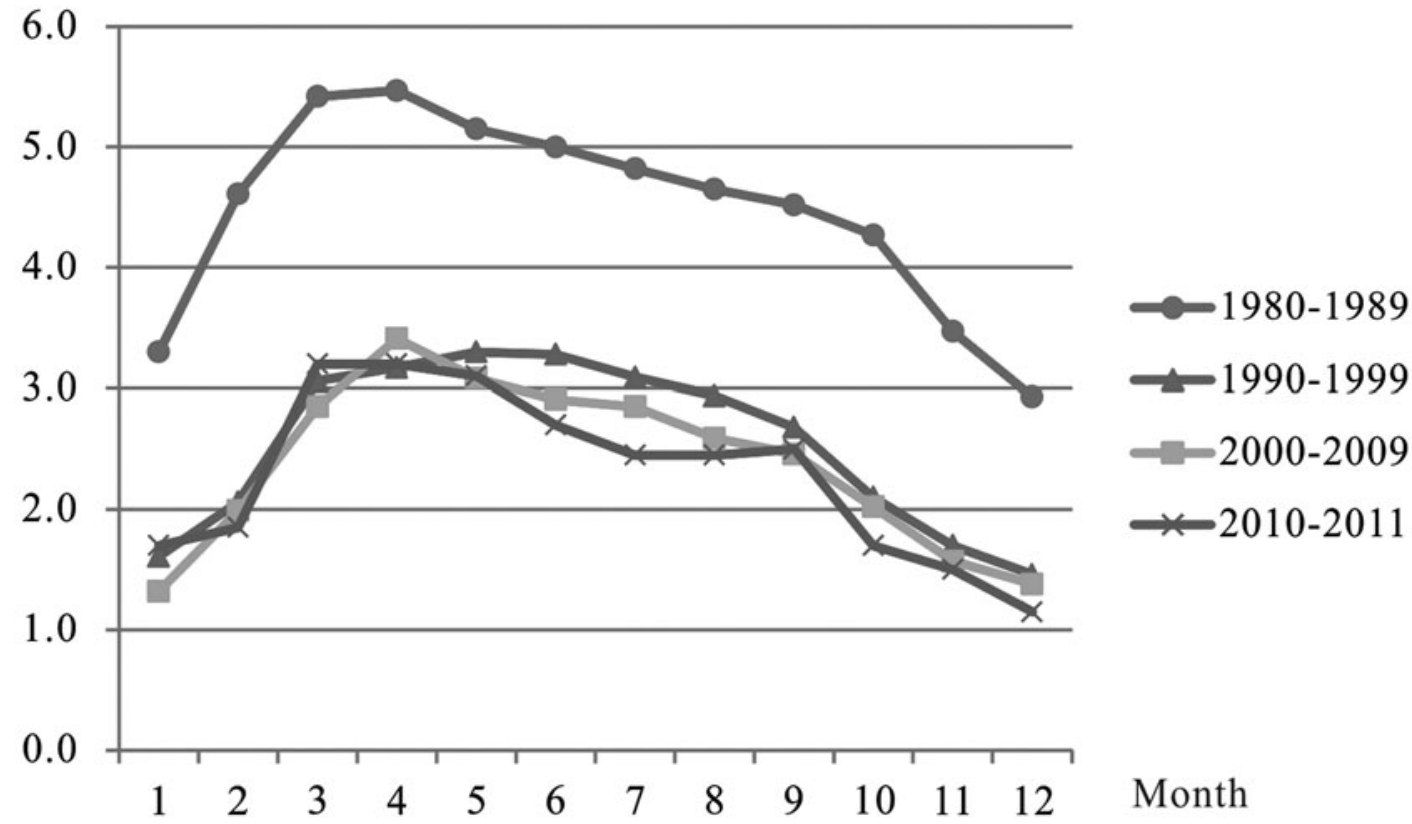

FIG. 8. Wind speed (monthly average) during 1989-2011 recorded at Mangya Meteorological Station (<50 km to DLT Playa). 


\section{Precipitation $(\mathrm{mm})$}

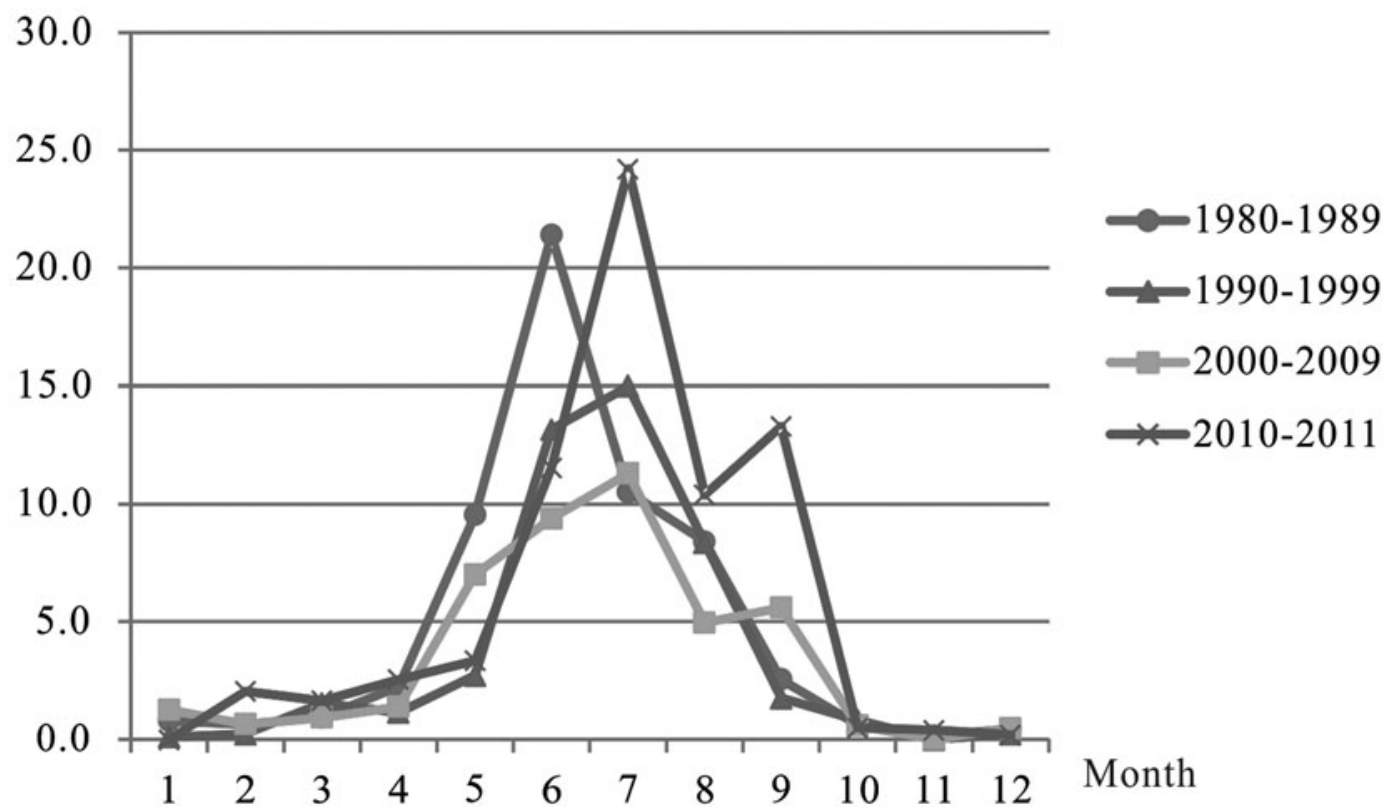

FIG. 9. Precipitation (monthly average) during 1989-2011 recorded at Mangya Meteorological Station (<50 km to DLT Playa).

monthly average wind speed occurs during spring (up to $3.5 \mathrm{~m} / \mathrm{s}$ ), and the minimum (about $1.5 \mathrm{~m} / \mathrm{s}$ ) occurs during winter (Fig. 8). The maximum wind speed can sometimes reach $20-22 \mathrm{~m} / \mathrm{s}$. A value of $20 \mathrm{~m} / \mathrm{s}$ was recorded at the DLT Playa weather station.

Rainfall events in the DLT area are shown in Table 2. The annual total precipitation averaged for 32 years (1980-2011) is about $50 \mathrm{~mm}$. Figure 9 shows that most precipitation (maximum $<25 \mathrm{~mm}$ monthly average) happens in the summer months. In contrast, the evaporation rate of this region is extremely high. The strong wind, solar irradiation, and lack of vegetation all lead to an annual total evaporation of $2590 \mathrm{~mm}$ as averaged for 32 years. Figure 10 shows that the strongest evaporation (maximum $\sim 440 \mathrm{~mm}$ per month)

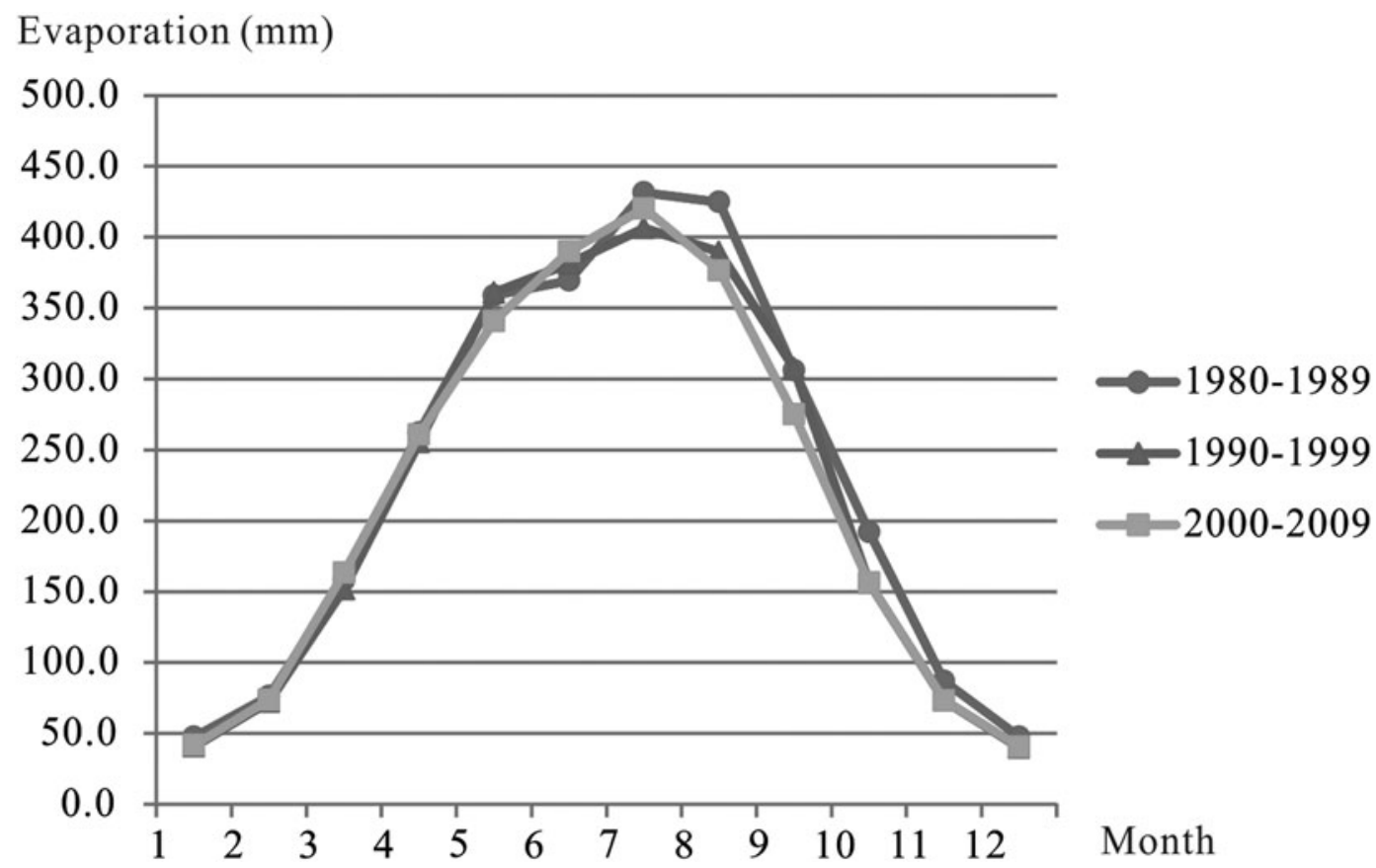

FIG. 10. Evaporation (monthly average) during 1989-2011 recorded at Mangya Meteorological Station (<50 km to DLT Playa). 
Pressure (mbar)

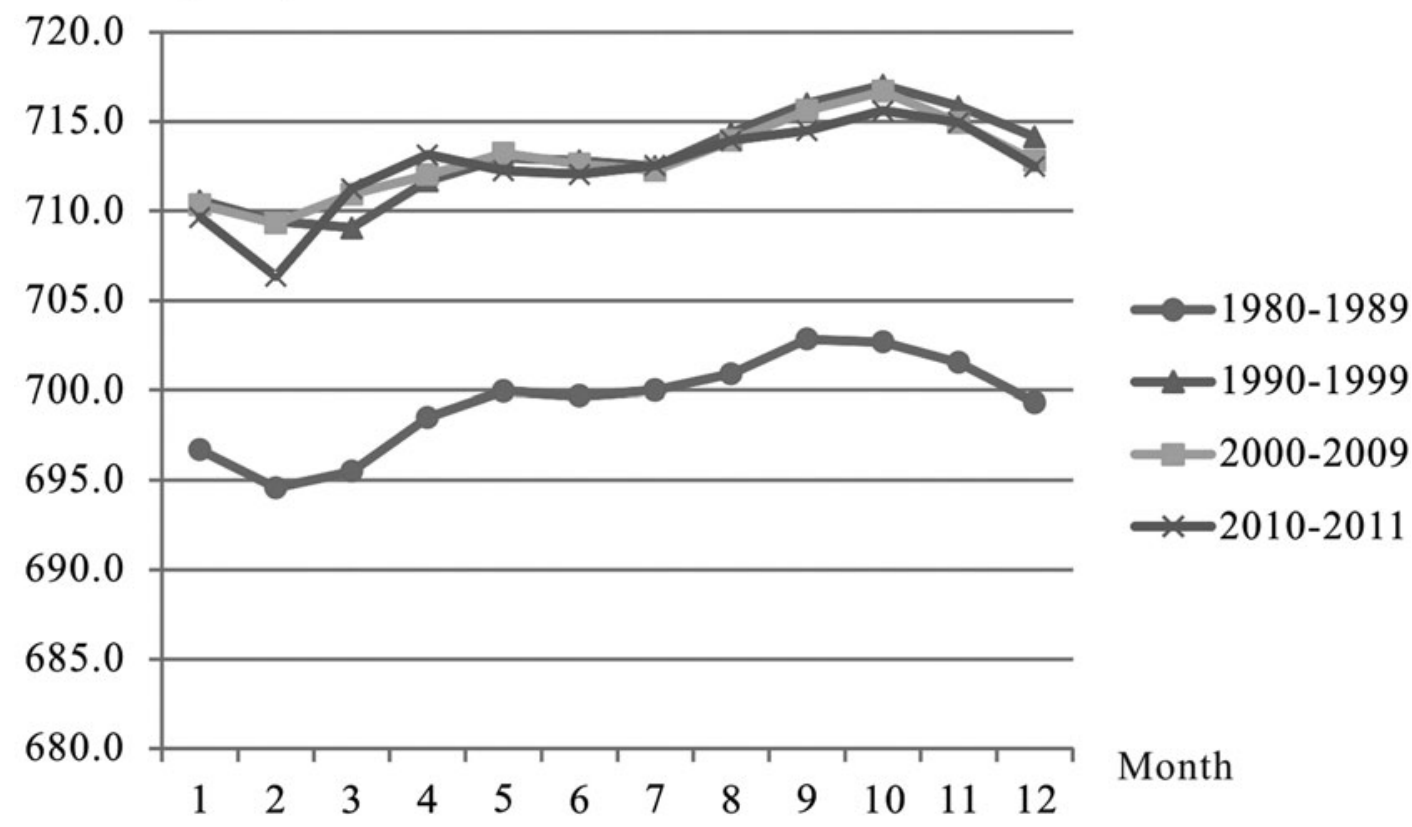

FIG. 11. Atmospheric pressure at surface (monthly average) during 1989-2011 recorded at Mangya Meteorological Station $(<50 \mathrm{~km}$ to DLT Playa).

Table 2. Measured Precipitation (In mm) from 1980 to 2011 at the Mangya Meteorological Station, Located $<50$ KM FROM the Dalangtan Playa

\begin{tabular}{|c|c|c|c|c|c|c|c|c|c|c|c|c|c|}
\hline Year & January & February & March & April & May & June & July & August & September & October & November & December & Total \\
\hline 1980 & 0.8 & 0.7 & 0.0 & 0.8 & 0.2 & 5.5 & 6.6 & 16.2 & 0.6 & 0.0 & 0.0 & 0.3 & 31.7 \\
\hline 1981 & 0.0 & 1.1 & 0.0 & 2.9 & 1.0 & 8.8 & 17.8 & 26.2 & 0.9 & 0.5 & 0.0 & 0.1 & 59.3 \\
\hline 1982 & 0.1 & 1.0 & 2.0 & 3.1 & 18.7 & 35.6 & 7.4 & 5.5 & 5.2 & 0.1 & 0.0 & 1.1 & 79.8 \\
\hline 1983 & 0.5 & 0.4 & 1.1 & 0.0 & 2.2 & 16.7 & 28.7 & 6.3 & 2.2 & 2.1 & 0.0 & 0.0 & 60.2 \\
\hline 1984 & 1.3 & 2.1 & 2.4 & 4.2 & 5.3 & 16.4 & 9.3 & 6.3 & 3.3 & 0.0 & 0.0 & 0.1 & 50.7 \\
\hline 1985 & 0.2 & 0.0 & 0.3 & 0.0 & 7.8 & 8.5 & 6.8 & 0.7 & 2.4 & 0.0 & 0.1 & 1.9 & 28.7 \\
\hline 1986 & 0.4 & 0.6 & 0.7 & 0.6 & 34.7 & 54.1 & 4.9 & 8.4 & 0.0 & 0.1 & 1.2 & 0.2 & 105.9 \\
\hline 1987 & 0.0 & 0.2 & 1.4 & 5.7 & 5.3 & 24.0 & 9.9 & 0.7 & 1.7 & 2.9 & 0.3 & 0.3 & 52.4 \\
\hline 1988 & 0.0 & 0.3 & 0.7 & 0.3 & 18.7 & 11.4 & 8.4 & 7.0 & 5.2 & 0.0 & 0.0 & 0.0 & 52.0 \\
\hline 1989 & 4.6 & 0.0 & 0.8 & 4.8 & 1.5 & 32.9 & 5.3 & 6.8 & 4.0 & 0.5 & 0.0 & 0.5 & 61.7 \\
\hline 1990 & 0.0 & 0.0 & 3.1 & 0.6 & 0.5 & 22.6 & 11.2 & 4.6 & 0.0 & 0.0 & 0.0 & 1.1 & 43.7 \\
\hline 1991 & 0.0 & 0.0 & 0.9 & 4.9 & 0.8 & 3.8 & 7.1 & 14.7 & 0.0 & 0.0 & 0.0 & 0.0 & 32.2 \\
\hline 1992 & 0.2 & 0.2 & 0.7 & 0.0 & 4.3 & 2.8 & 27.6 & 0.5 & 0.1 & 2.0 & 0.0 & 0.2 & 38.6 \\
\hline 1993 & 0.6 & 0.9 & 1.6 & 0.0 & 1.8 & 45.0 & 27.1 & 8.9 & 0.0 & 0.0 & 0.0 & 1.1 & 87.0 \\
\hline 1994 & 0.0 & 0.3 & 0.0 & 0.0 & 0.2 & 4.6 & 12.4 & 4.0 & 0.0 & 0.8 & 0.0 & 0.0 & 22.3 \\
\hline 1995 & 0.1 & 1.0 & 0.0 & 5.2 & 0.0 & 4.1 & 2.1 & 3.6 & 12.0 & 4.7 & 0.0 & 0.0 & 32.8 \\
\hline 1996 & 0.0 & 0.0 & 2.0 & 0.8 & 7.7 & 7.3 & 29.1 & 13.0 & 0.8 & 0.4 & 0.0 & 0.0 & 61.1 \\
\hline 1997 & 0.0 & 0.0 & 0.0 & 0.0 & 11.0 & 8.8 & 8.3 & 18.2 & 0.0 & 0.0 & 0.0 & 0.0 & 46.3 \\
\hline 1998 & 0.2 & 0.0 & 4.7 & 0.0 & 0.6 & 13.7 & 11.9 & 11.2 & 4.7 & 0.2 & 0.0 & 0.0 & 47.2 \\
\hline 1999 & 0.0 & 0.0 & 2.4 & 0.0 & 0.3 & 19.0 & 13.2 & 4.9 & 0.0 & 0.2 & 0.0 & 0.0 & 40.0 \\
\hline 2000 & 1.9 & 0.5 & 0.0 & 0.2 & 1.6 & 16.4 & 12.5 & 7.2 & 4.9 & 0.0 & 0.0 & 0.0 & 45.2 \\
\hline 2001 & 0.0 & 0.4 & 0.0 & 0.0 & 0.8 & 3.9 & 1.1 & 5.8 & 0.1 & 0.0 & 0.0 & 0.0 & 12.1 \\
\hline 2002 & 2.6 & 0.0 & 0.1 & 7.1 & 0.6 & 13.8 & 7.0 & 2.7 & 6.6 & 0.3 & 0.0 & 0.8 & 41.6 \\
\hline 2003 & 0.0 & 1.4 & 3.1 & 0.9 & 4.1 & 21.0 & 14.7 & 0.0 & 2.6 & 0.3 & 0.0 & 0.2 & 48.3 \\
\hline 2004 & 0.7 & 0.0 & 0.1 & 0.7 & 1.6 & 6.7 & 1.6 & 5.2 & 0.0 & 0.0 & 0.1 & 0.1 & 16.8 \\
\hline 2005 & 0.0 & 2.2 & 5.4 & 0.0 & 32.4 & 2.6 & 22.5 & 21.3 & 0.6 & 1.3 & 0.0 & 0.0 & 88.3 \\
\hline 2006 & 1.6 & 0.8 & 0.0 & 4.1 & 6.0 & 2.0 & 12.0 & 3.0 & 4.2 & 0.3 & 0.0 & 2.4 & 36.4 \\
\hline 2007 & 0.0 & 0.0 & 0.1 & 0.9 & 2.7 & 17.8 & 14.6 & 0.3 & 11.9 & 1.8 & 0.0 & 0.0 & 50.1 \\
\hline 2008 & 5.8 & 0.0 & 0.2 & 0.0 & 12.6 & 8.7 & 20.7 & 4.1 & 24.8 & 1.9 & 0.0 & 0.2 & 79.0 \\
\hline 2009 & 0.0 & 1.2 & 0.3 & 0.0 & 7.7 & 1.0 & 6.3 & 0.0 & 0.2 & 0.0 & 0.0 & 1.1 & 17.8 \\
\hline 2010 & 0 & 4.1 & 2.5 & 3.1 & 4.7 & 10.5 & 42.1 & 5.3 & 22.7 & 0.9 & 0 & 0.4 & 96.3 \\
\hline 2011 & 0 & 0 & 0.8 & 2 & 2 & 12.6 & 6.3 & 15.5 & 3.9 & 0.1 & 0.8 & 0 & 44.0 \\
\hline
\end{tabular}


occurs in the high $\mathrm{T}$ summer months. The AI of the DLT area, as defined by the annual total precipitation over annual total evaporation, is about 0.02 (variation over month is 0.01-0.05; Figs. 9 and 10), which classifies the DLT area as a hyperarid region on Earth.

\section{DLT May Provide Some Interesting Case Studies for Mars Potential Habitability}

On the basis of the already reported occurrence of salt deposits in the three playas of Qaidam Basin (including the DLT Playa), and the regional meteorological patterns, we believe that the DLT area and the local region in general can serve as a Mars analog site that is consistent with desert-type terrain and applicable for investigation of the fundamental properties of hydrous salts in a natural setting under Mars-relevant environmental conditions, such as the precipitation of salts from a natural $\mathrm{Na}-\mathrm{K}-\mathrm{Ca}-\mathrm{Mg}-\mathrm{Cl}-\mathrm{SO}_{4}-\mathrm{CO}_{3}-\mathrm{H}_{2} \mathrm{O}$ system and their phase transformation or preservation under hyperarid conditions. Because similar types of hydrous salt deposits (magnesiumsulfates) at the surface of DLT were identified on Mars, the DLT area can also serve as an orbital remote sensing test region for the use of Vis-NIR spectroscopy, with known ground truth, and for the Operation Readiness Test of future landed missions to Mars (e.g., China's Mars 2020 mission).

The diverse salts with different chaotropic or kosmotropic properties in the Qaidam Basin (especially $\mathrm{MgCl}_{2} \cdot 6 \mathrm{H}_{2} \mathrm{O}$ and $\mathrm{CaCl}_{2} \cdot 6 \mathrm{H}_{2} \mathrm{O}$ in the Kunteyi Playa) may provide some interesting case studies for Mars regarding potential habitability.

$\mathrm{T}$ and water activity are the most important physical parameters that influence microbial metabolism and growth (Beaty et al., 2006). A limit of $\mathrm{T} \geq-25^{\circ} \mathrm{C}$ and water activity $>0.5$ has been recommended for considering Special Regions on Mars (Kminek et al., 2010). Future field exploration of the DLT region would enable detailed study of these parameters along with biomarker identification within salt deposits on-site and in laboratory study.

\section{Acknowledgments}

The authors thank Dr. Weigang Kong and Academician Wenjin Zhao for their help in preparing this article. This research was funded by the China Geological Survey program "Astrobiology on Mars analogous sites for saline environments" (Grant No. 12120113019100) and "The comprehensive survey of lithium, and other resources in salt lakes on the Tibetan Plateau" (Grant Nos. 121201103000150012 and DD20160025). A.W. and P.S. would like to express their great appreciation to the McDonnell Center for Space Science at Washington University in St. Louis for its generous financial support for the 2008 field expedition to Qaidam Basin, Tibetan Plateau, the laboratory sample analysis (2009-2012), and the article preparation (2014-2016). There are no competing financial interests existing for all authors of this article.

\section{Authors' Disclosure Statement}

No competing financial interests exist.

\section{References}

Anglés, A. and Li, Y. (2017a) The western Qaidam Basin as a potential Martian environmental analogue: an overview. J Geophys Res Planets 122:856-888.
Anglés, A. and Li, Y.L. (2017b) Similar ring structures on Mars and Tibetan Plateau confirm recent tectonism on Martian northern polar region. Int J Astrobiol 16:355-359.

Beaty, D., Buxbaum, K., Meyer, M., Barlow, N., Boynton, W., Clark, B., Deming, J., Doran, P.T., Edgett, K., Hancock, S., Head, J., Hecht, M., Hipkin, V., Kieft, T., Mancinelli, R., McDonald, E., McKay, C., Mellon, M., Newsom, H., Ori, G., Paige, D., Schuerger, A.C., Sogin, M., Spry, J.A., Steele, A., Tanaka, K., and Voytek, M. (2006) Findings of the Mars Special Regions Science Analysis Group. Astrobiology 6: 677-732.

Cheng, Z., Xiao, L., Wang, H., Yang, H., Li, J., Huang, T., Xu, Y., and Ma, N. (2017) Bacterial and archaeal lipids recovered from subsurface evaporites of Dalangtan Playa on the Tibetan Plateau and their astrobiological implications. Astrobiology 17:1112-1122.

Haar, L., Gallagher, J.S., and Kell, G.S. (1984) NBS/NRC Steam Tables. Hemisphere Publishing Corp., New York, NY.

Kminek, G., Rummel, J.D., Cockell, C.S., Atlas, R., Barlow, N., Beaty, D., Boynton, W., Carr, M., Clifford, S., Conley, C.A., Davila, A.F., Debus, A., Doran, P., Hecht, M., Heldmann, J., Helbert, J., Hipkin, V., Horneck, G., Kieft, T.L., Klingelhoefer, G., Meyer, M., Newsom, H., Ori, G.G., Parnell, J., Prieur, D., Raulin, F., Schulze-Makuch, D., Spry, J.A., Stabekis, P.E., Stackebrand, E., Vago, J., Viso, M., Voytek, M., Wells, L., and Westall, F. (2010) Report of the COSPAR Mars special regions colloquium. Adv Space Res 46:811-829.

Kong, F.J., Zheng, M.P., Wang, A., and Ma, N.N. (2009) Endolithic halophiles found in evaporite salts on Tibet Plateau as a potential analog for Martian life in saline environment [abstract 1216]. In 40th Lunar and Planetary Science Conference Abstracts, Lunar and Planetary Institute, Houston.

Kong, F.J., Ma, N.N., Wang, A., and Amend, J. (2010) Isolation and identification of halophiles from evaporates in DaLangTan salt lake. Acta Geologica Sinica (in Chinese) 84:1661-1667.

Kong, W.G., Zheng, M.P., and Kong, F.J. (2014a) Brine evolution in Qaidam Basin, northern Tibetan Plateau, and the formation of playas as Mars analogue site [abstract 1228]. In 45th Lunar and Planetary Science Conference Abstracts, Lunar and Planetary Institute, Houston.

Kong, W.G., Zheng, M.P., Kong, F.J., and Chen, W.X. (2014b) Sulfate-bearing deposits at Dalangtan Playa and their implication for the formation and preservation of Martian salts. Am Mineral 99:283-290.

Mayer, D.P., Arvidson, R.E., Wang, A., Sobron, P., and Zheng, M.P. (2009) Mapping minerals at a potential mars analog site on the Tibetan Plateau [abstract 1877]. In 40th Lunar and Planetary Science Conference Abstracts, Lunar and Planetary Institute, Houston.

Mohlmann, D. and Thomsen, K. (2011) Properties of cryobrines on Mars. Icarus 212:123-130.

Sobron, P., Freeman, J.J., and Wang, A. (2009) Field test of the water-wheel IR (WIR) spectrometer on evaporative salt deposits at Tibetan Plateau [abstract 2372]. In 40th Lunar and Planetary Science Conference Abstracts, Lunar and Planetary Institute, Houston.

Sobron, P., Wang, A., Mayer, D.P., Bentz, J., Kong, F., and Zheng, M. (2018) Dalangtan saline playa in a hyperarid region on Tibet Plateau-III: Correlated multiscale surface mineralogy and geochemistry survey. Astrobiology 18:000-000.

Wagner, W., Saul, A., and Pruss, A. (1994) International equations for the pressure along the melting and along the sublimation curve of ordinary water substance. J Phys Chem Ref Data 23:515-525. 
Wang, A. and Zheng, M.P. (2009) Evaporative salts from Saline Lakes on Tibetan Plateau: an analog for salts on Mars [abstract 1858]. In 40th Lunar and Planetary Science Conference Abstracts, Lunar and Planetary Institute, Houston.

Wang, A. and Zheng, M.P. (2011) Saline Playa on Qinghai Tibet Plateau [abstract 6003] In Analogue sites for the Mars Missions: MSL and Beyond, Lunar and Planetary Institute, Houston.

Wang, A., Zheng, M.P., Kong, F.J., Sobron, P., and Mayer, D. (2010) Saline playas on Qinghai-Tibet Plateau as Mars ana$\log$ for the formation-preservation of hydrous salts and biosignaturess [abstract for 2010]. In Fall AGU.

Wang, A., Lu, Y.L., and Chou, I.M. (2013) Recurring slope lineae (RSL) and subsurface chloride hydrates on Mars [abstract 2606]. In 44th Lunar and Planetary Science Conference Abstracts, Lunar and Planetary Institute, Houston.

Wang, A., Sobron, P., Kong, F., Zheng, M.P., and Zhao, Y. (2018) Dalangtan saline playa in a hyperarid region on Tibet Plateau-II: Preservation of salt with high hydration degrees in subsurface. Astrobiology 18:000-000.

Wang, K.L., Jiang, H., and Zhao, H.Y. (2005) Atmospheric water vapor transport from westerly and monsoon over the Northwest China. Adv Water Sci 16:432-438 (in Chinese).

Xiao, L., Wang, J., Dang, Y.N., Cheng, Z.Y., Huang, T., Zhao, J.N., Xu, Y., Huang, H., Xiao, Z.Y., and Komatsu, G. (2017) A new terrestrial analogue site for Mars research: the Qaidam Basin, Tibetan Plateau (NW China). Earth Sci Rev 164:84-101.

Zhang, P.X. (1987) Salt lakes on Qaidam Basin. The Science Publishing House (in Chinese), Beijing.

Zheng, M. (1997) An Introduction to Saline Lakes on the Qinghai-Tibet Plateau. Springer, Netherlands.

Zheng, M.P., Wang, A., Kong, F.J., and Ma, N.N. (2009) Saline lakes on Qinghai-Tibet Plateau and salts on Mars [abstract
1454]. In 40th Lunar and Planetary Science Conference Abstracts, Lunar and Planetary Institute, Houston.

Zhu, Y.T., Zhong, J.H., and Li, W.S. (1994) The Neotectonic Movement and the Evolution of Saline Lakes of Qaidam Basin in Northwestern China. Geological Publishing House (in Chinese), Beijing.

Address correspondence to: Fanjing Kong

MLR Key Laboratory of Saline Lake Resources and Environments Institute of Mineral Resources Chinese Academy of Geological Sciences 26 Bai Wan Zhuang Street Beijing 100037

China

E-mail: kongjie69@hotmail.com

Submitted 6 February 2018

Accepted 13 March 2018

Associate Editor: Christopher McKay

$$
\begin{aligned}
& \text { Abbreviations Used } \\
& \mathrm{AI}=\text { aridity index } \\
& \text { DLT }=\text { Dalangtan } \\
& \mathrm{QT}=\text { Qinghai-Tibet } \\
& \mathrm{RH}=\text { relative humidity } \\
& \mathrm{T}=\text { temperatures }
\end{aligned}
$$

